\title{
The Effect of Discovery Learning Model on Students' Ability in Determining Character Education Values in Folklore at The Tenth-Grade Students of SMA Negeri 3 Ambon, Indonesia
}

\author{
Tasya Yoris ${ }^{1}$ Everhard Markiano Solissa ${ }^{2}$ Iwan Rumalean $^{3}$ \\ Department of Indonesian Language and Literature, FKIP Universitas Pattimura \\ Jalan Ir. M. Putuhena Kampus FKIP Unpatti Poka - Ambon 97234 Indonesia
}

\begin{abstract}
This research is financed by a research grant in 2019, Faculty of Teacher Training and Education, Pattimura University, Ambon, Indonesia.

Abstract

This research is aimed at finding out the effect of the discovery learning model on students' ability in determining character education values in folklore at the tenth-grade students of SMA Negeri 3 Ambon. This belongs to experimental research. This research data is the students' test results in determining character education values in folklore. The number of the sample is 38 students (the experimental class) and 35 students (the control class). SPSS version 23 is used to analyze the data. The result shows that there is an effect of the discovery learning model on students' ability in determining character education values in folklore at the tenth-grade students of SMA Negeri 3 Ambon. It is proved through the result of the independent sample $t$-test which is $t$-count $>t$-table $(4.353>1.994)$. Keywords: experimental research, discovery learning model, learning achievement, character education values. DOI: $10.7176 / \mathrm{JEP} / 11-29-07$
\end{abstract}

Publication date:October $31^{\text {st }} 2020$

\section{Introduction}

1.1 Background of The Study

Education plays an important role in human life. Through education, human life can be formed into a better one. A good education can prepare and equip students with knowledge, attitudes, and skills. Education is not only obtained in formal educational institutions but also non-formal institutions such as within the family and in one's surrounding environment. In other words, education can be obtained anywhere and anytime.

(Wibowo, 2013) states that education should be able to provide a place for self-empowerment based on its character, paradigm, and motives. Therefore, in advancing education, character education is an important requirement for today's young generation. It is a means of shaping a person's morals or character for the better one so that they can be free from the bad things.

Ideally, literature learning can significantly contribute to the success of the desired human development. This can be obtained as long as it is carried out with the right approach, i.e. an approach that can stimulate the occurrence of exercise. This study uses one of the genres of oral literature, namely folklore as a means of determining character education values. (Supratno \& Darni, 2015) state that national character education through literary works is very important and it is following the current condition of Indonesian society which is experiencing a moral and ethical decline. The deterioration can be seen in one's behavior, attitudes, and speech. Furthermore, it is said that the values in oral literature can be actualized in everyday life and are used as guidelines in family, community, nation, and state (Supratno, 2010).

In each lesson, there are defined criteria to measure the students' ability to understand the material being taught. One of them is the minimum completeness criteria (KKM). The KKM set in the Indonesian language course at SMA Negeri 3 Ambon is 75. Achieving the KKM requires the seriousness of both teachers and students. Teachers make efforts to achieve KKM by maximizing the learning and assessment process. Meanwhile, students are expected to be able to prepare themselves and be proactive when the teaching and learning process is in progress.

One way to achieve these expectations is to apply the discovery learning model. It is an effective and efficient learning model. It helps students detect problems that they will learn on their own. Through the discovery learning model, they can learn to think analytically and think creatively. It has been widely used in research such as those conducted by Kristin \& Rahayu (2016), Atikah (2017), Zulastri (2017), Septiani (2018), Kuncoro (2018), and Reinita (2019). It shows that the discovery learning model has a positive influence on students' learning outcomes for all courses at every level of education.

\subsection{Research Question}

The research question is that "Is there an effect of the discovery learning model on students' ability in determining character education values in folklore at the tenth-grade students of SMA Negeri 3 Ambon?" 


\subsection{Hypothesis}

The research hypothesis is that "there is an effect of the discovery learning model on students" ability in determining character education values in folklore at the tenth-grade students of SMA Negeri 3 Ambon".

\section{Theoretical Review}

\subsection{Character Education}

All people agree that character education is important to create quality successors. It is one way to guide someone in good behavior so that they can avoid all bad things. Government regulation through the Ministry of Education and Culture regarding character education in the 2013 curriculum must be welcomed and supported by all parties. Character education is not only important but also necessary for every nation if it wants to become a civilized nation (Kurniasih \& Sani, 2017).

Furthermore, it is said that a more basic view regarding the purpose of character education is to build a person's character and make it better, where that character will dominate the character or identity of that person. This character education focuses on spiritual morality in order to produce ethical individuals. According to Kurniasih \& Sani (2017), the purpose of character education is to form a personality that is formed in the main unity between subjects through their attitudes and behaviors. This is in line with Solissa's opinion who mentions that in oral literature, there are character education values in the form of hard work, mutual respect, humility, obedience, social life, and exemplary (Solissa, 2019).

Literature teaching is closely related to character education because literature talks about the value of life that is directly related to the human character that has been formed. Literature in children's education can play a role in developing cognitive, affective, psychomotor aspects, and developing personality (Nurhayati in Wibowo, 2013). Firmansyah (in Wibowo, 2013) states that literature does not only function as an agent of education, shaping a person's personality but also to refine individuals and societies to become a civilized society.

Ideally, literary teaching can contribute significantly to the success of the desired human development. This can be obtained as long as it is carried out with the right approach, namely an approach that can stimulate thinking. Intermediate (in Wibowo 2013: 136) language and literature teaching can support each other if both are implemented with the right approach.

Haryadi (in Wibowo 2013) the role of literature in shaping the character of the nation is not only based on the values contained therein. Appreciative literary learning is also full of character education. Reading, listening, and watching literary activities essentially instill a character of diligence, critical thinking, and broad insight. At the same time feeling sensitivity is developed so that readers tend to love goodness and share the truth.

There are 18 values developed in the culture and character education of the nation (Kemendiknas in Kurniasih and Sani, 2017), namely: (1) Religious. Tolerance attitudes and behavior towards the implementation of the worship of other religions, living in harmony with followers of other religions is obedient behavior in carrying out the teachings of their religion, (2) Honest. Behavior which is the basis of efforts to make himself a person who can be trusted in both actions, words and jobs, (3) Tolerance. Attitudes, ethnicity, ethnicity and actions that respect religious differences are the actions of other people who are different on themselves, (4) Discipline. Actions that show obedient and orderly behavior to various rules and regulations, (5) Hard Work. Behavior shows a serious effort to solve assignment problems and learn by completing assignments well, (6) Creative. Thinking to produce something in a new and existing way, (7) Independent. Attitude, behavior in completing tasks that are not easy and not dependent on others, (8) Democratic. The way of thinking, behaving and acting assesses the rights with the obligations of oneself and of others, (9) Curiosity. Actions and attitudes will be deeper, wider and always try to know something that is learned, heard and seen, (10) National Spirit. The way of thinking, having insight and acting is placed in the interests of the nation and state outside of the interests of groups and individuals, (11) Love the Motherland. Having attitude, loyalty, way of thinking, and respecting the nation's language, culture, economy, physical, social and political environment (12) Respect. Attitude is an act that encourages a person to produce things that are useful for the community and respect the success of others, (13) Friendly/Communicative. Actions by seeing a sense of pleasure, socializing, talking and cooperating with others, (14) Love Peace. Attitudes, actions and words that involve other people feeling happy and safe in his presence, (15) Love to Read. The habit of putting aside time for reading and giving self-righteousness to various readings, (16) Care for the Environment. Actions and attitudes that prevent damage to the surrounding environment and development to repair natural damage that has occurred, (17) Social Care. Actions and attitudes want to provide assistance to communities in need and to others, (18) Responsibility. Behavior and attitude to carry out duties and obligations that must be done to God Almighty, the country, the environment, society, and yourself.

\subsection{Folklore}

Folk tales are part of folklore. Supratno \& Darni (2015) state that folklore is one element of culture which has various types, such as (1) oral folklore, (2) semi-oral folklore, and (3) non-verbal folklore. Various types of folklore contain cultural values that can be used as a medium for national character education in general and students in 
particular. Folklore can also be defined as cultural expressions of the local community through stories that are directly related to various aspects of the social and cultural values of the community. In the past, folklore was passed down from generation to generation orally (Hutomo, 1991).

Folklore is an inseparable part of the culture and history of a nation. Usually, folklore describes various things that happen, such as the occurrence of the universe, place, or an important event. In Indonesian literature, a folk tale is a form of oral folklore. The word folklore itself is an Indonesian translation of English folklore. Folk means collective, namely a group of people who differentiate it from other groups through physical, social, and cultural characteristics, while lore means tradition. Folk is a culture that is passed down from generation to generation, verbally, or through examples accompanied by gestures or reminders (Danandjaja, 1997).

Hamidy (2003) states that the social functions of folklore include entertainment, solace, self-respect, and even as a means of education. In this regard, (Atmazaki, 2007) argues that the social functions of oral literature include: (1) to refresh thoughts and feelings and even strengthen solidarity, (2) can be used to praise the king, people who are considered sacred, authoritative, and even holy, (3) used as a reflection about the life of ancient society or our ancestors and is also used to express the turmoil of the soul.

\subsection{Discovery Learning Model}

The learning model used in the research is discovery learning. It emphasizes the students' ability to find information and understand the concept of learning independently based on their abilities with the teacher's guidance and supervision. According to Budiningsih (2005), discovery learning is a way of learning to understand concepts, meanings, and relationships through an intuitive process to finally conclude. The application of the discovery learning model has stages that must be considered so that learning is following the objectives to be achieved. Syah (2004) states that the stages of the discovery learning model are (1) stimulation, (2) problem statement, (3) data collection, (4) data processing, (5) verification, and (6) generalization.

According to Alma, et al (2010), the steps of applying the dicovery learning model are:

1. Stimulation

At this stage, students will first be faced with something that can lead to questions to be solved by students.

The teacher can start the teaching and learning process by asking questions, suggesting reading books, and other learning activities that lead to problem-solving preparation. So, at this stage a problem will be given that will stimulate the desire of students to carry out an investigation.

1. Problem Statement

After being given the stimulus, the next step is that students are given the opportunity to identify problems related to the lesson, then students are guided to formulate a hypothesis.

2. Data Colletion

When exploration takes place, the teacher also provides opportunities for students to collect as much relevant information as possible to prove whether the hypothesis is true or not. Thus, students are given the opportunity to collect (collection) various relevant information, read literature, observe objects, interview with sources, conduct their own trials and so on.

3. Data Processing

All information from reading results, interviews, observations and so on, must be processed, randomized, classified, tabulated, even if necessary, it is calculated in a certain way and interpreted at a certain level of confidence. At this stage students must process all the data and information that has been obtained.

4. Verification

At this stage, students are required to carry out careful examinations to prove whether or not the predetermined hypothesis is true with alternative findings, linked to the results of data processing.

5. Generalization

The generalization stage or drawing conclusions is the process of making conclusions that can be used as general principles and applies to all the same events or problems by taking into account the results of verification or evidence.

\section{Method}

\subsection{Research Design}

This research was quantitative. According to Sugiyono (2017), quantitative research data is in the form of numbers and is analyzed by using statistics. This study used a quasi-experimental design method with a nonequivalent control group design. Thus, this study used two classes, namely the experimental class (X MIPA 1), which amounts to 38 students, and the control class (X IPS 3), which amounts to 35 students. The data obtained by observation, interview, and test. The data gathered from the test were used as the main data and were analyzed using SPSS version 23. 


\subsection{Variables}

In this study, there are two variables, namely the independent variable and the dependent variable.

1. Independent Variable

Independent variable is variable that affect or cause changes in the dependent variable (Sugiyono, 2017). The independent variable in this study is "the application of discovery learning learning models". This variable is usually symbolized or denoted by the variable "X" (Martono, 2010).

2. Dependent Variable

The dependent variable is the variable that is influenced by or that is the result of the independent variable (Sugiyono, 2017). The dependent variable in this study is "the ability to determining character education values in the folklore at The Tenth-Grade of SMA Negeri 3 Ambon". This variable is usually symbolized or denoted by the variable "Y" (Martono, 2010).

\subsection{Sample}

This study used 2 classes as a sample, namely class X MIPA-1 with 38 students as the experimental class (which applied discovery learning model), and class X IPS-3 with 35 students as the control class (which applied the conventional model). The sample determination of the two classes is based on the level of ability which is equivalent. The samples were determined by using purposive sampling technique.

\subsection{Data Analysis Technique}

In this study, using the test instrument validity test with the Pearson Bivariate Correlation Method in the SPSS version 23 program with menu analyze $>$ correlate $>$ bivariate. To find out whether the test instrument is valid or not, it can be seen in the SPSS correlations output. Meanwhile, to determine whether an item is valid or not is to compare $r$ count with $r$ table. If $r$ count $<r$ tabel then the item value is declared invalid. The criteria for the items were declared valid if $r$ count $>r$ tabel or at a significance level of 0.05 .

Table 1. Instrument Validity Criteria

\begin{tabular}{|l|l|}
\hline Validity Coefficient & Interpretative \\
\hline $\mathrm{r} \leq 0,00$ & Not valid \\
\hline $0,00<\mathrm{r} \leq 0,20$ & Very low validity \\
\hline $0,20<\mathrm{r} \leq 0,40$ & Low validity \\
\hline $0,40<\mathrm{r} \leq 0,60$ & Medium validity \\
\hline $0,60<\mathrm{r} \leq 0,80$ & High validity \\
\hline $0,80<\mathrm{r} \leq 1,00$ & Very high validity \\
\hline
\end{tabular}

Testing the level of reliability in this study using the Pearson Correlation Analysis Method in the SPSS version 23 program with menu the analyze $>$ scale $>$ reliability analysis. To be able to determine whether the test instrument is reliable or not, it can be seen in the SPSS cronbach alpha output. Reliability $<0.6$ is not good, while 0.7 is acceptable and above 0.8 is good (Priyatno, 2017).

Table 2. Instrument Reliability Criteria

\begin{tabular}{|l|l|}
\hline Reliability Coefficient & Interpretative \\
\hline $0,80 \leq \mathrm{r}$ & High degree of reliability \\
\hline $0,40 \leq \mathrm{r}<0,80$ & Medium degree of reliability \\
\hline $\mathrm{r}<0,40$ & Low degree of reliability \\
\hline
\end{tabular}

To test the normality, the SPSS version 23 program is used with menu analyze descriptive statistics $>$ explore $>$ plots $>$ normality plots with test continue $>O K$. To find out whether the research data is normal or not, it can be seen in the SPSS test output of normality of the Shapiro-Walk Table, column sig. If the significance value $>0.05$, the data is normally distributed.

To test the homogeneity, the SPSS 23 program is used with menu analyze $>$ compare means $>$ one-way anova $>$ options (statistics) $>$ homogeneity of variance test $>$ continue $>O K$. The decision is made if the significance value is more than $0.05(>0.05)$ then the variants of the data group are the same. Meanwhile, if the significance value is less than $0.05(<0.05)$, the variants of the data groups are not the same.

To test the hypothesis, the independent samples $t$ test was used to test the difference in the mean of the two groups or independent samples. The menu used in the SPSS version 23 program in this study is Analyze, compare means, independent samples, test, define group, continue, ok. The test criteria based on the significance value is if the significance is more than $0.05(>0.05)$ then $\mathrm{H}_{0}$ is accepted and if the significance is less than $0.05(<0.05)$ then $\mathrm{H}_{0}$ is rejected.

\section{Result}

4.1 Students' Pretest Data in Experimental and Control Classes

In this study, the researchers carried out a pretest in the experimental and the control classes which is aimed at 
knowing the students' initial abilities in both classes. The pretest results were presented in the following table.

Table 3. Students' Pretest Data for The Experimental and Control Classes

\begin{tabular}{|c|l|c|c|}
\hline \multirow{2}{*}{ No } & \multirow{2}{*}{ Data Criteria } & \multicolumn{2}{|c|}{ Class } \\
\cline { 3 - 4 } & & Experiment & Control \\
\hline 1 & Total Students & 38 & 35 \\
\hline 2 & Average Score & 61.66 & 51.37 \\
\hline 3 & Minimum Score & 44 & 19 \\
\hline 4 & Maximum Score & 88 & 81 \\
\hline 5 & Median & 63 & 56 \\
\hline 6 & Mode & 63 & 56 \\
\hline
\end{tabular}

Table 3 showed some data, i.e. the average score in the experimental class was 61.66 with details: a minimum score (44), a maximum score (88), a median (63), and a mode (63). The average score of the control class was 51.37 with details: the minimum score (19), the maximum score (81), the median (56), and the mode (56). A frequency distribution is the grouping of data into several classes. The following is the frequency histogram of the pretest score in experimental and control classes.

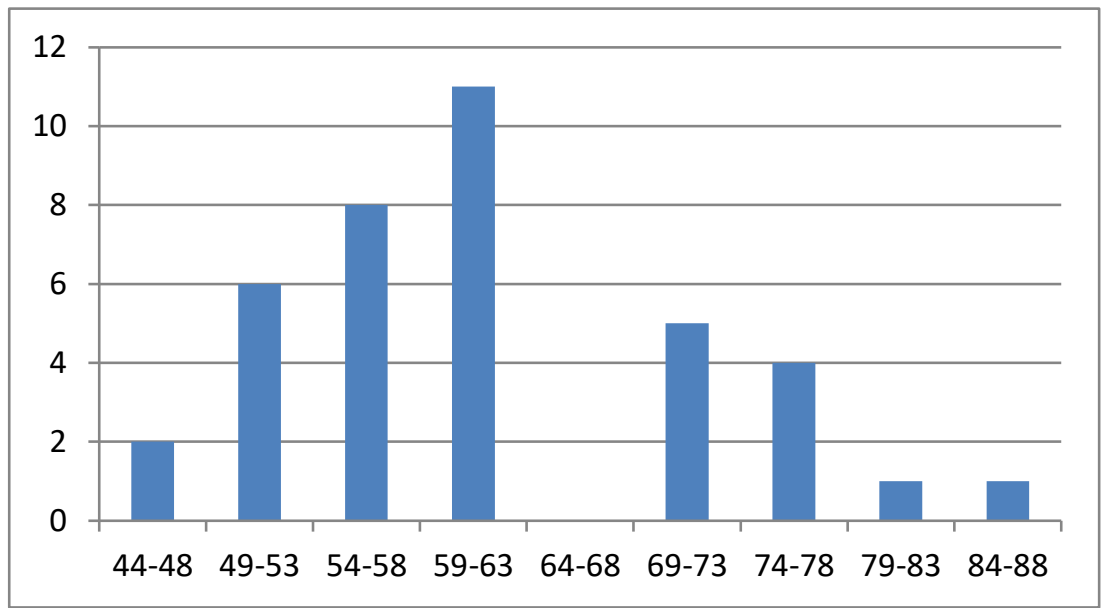

Figure 1. The histogram of the frequency distribution of experimental class pretest score

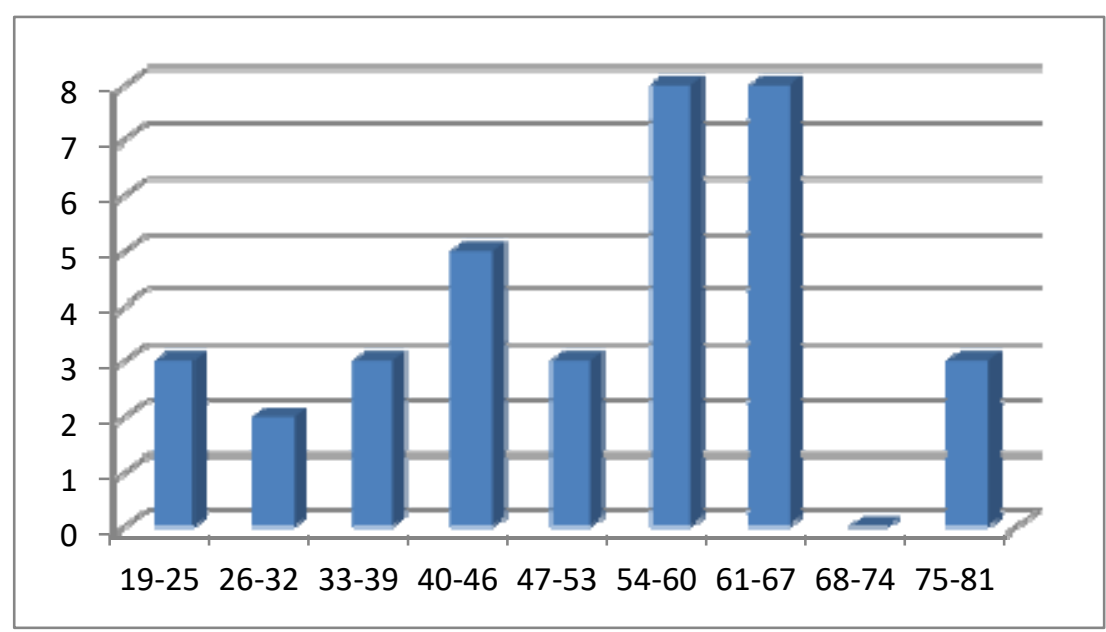

Figure 2. The histogram of the frequency distribution of control class pretest score

\subsection{Students' Posttest Data in Experimental and Control Classes}

The posttest was carried out in experimental and control classes to determine the students' final ability after being given folklore material. The following was a description of the posttest result data. 
Table 4. Posttest Data for The Experimental and Control Classes

\begin{tabular}{|c|l|c|c|}
\hline \multirow{2}{*}{ No } & \multirow{2}{*}{ Data Criteria } & \multicolumn{2}{|c|}{ Class } \\
\cline { 3 - 4 } & & Experiment & Control \\
\hline 1 & Total Students & 38 & 35 \\
\hline 2 & Average Score & 72.53 & 61 \\
\hline 3 & Minimum Score & 50 & 44 \\
\hline 4 & Maximum Score & 100 & 81 \\
\hline 5 & Median & 75 & 63 \\
\hline 6 & Mode & 75 & 63 \\
\hline
\end{tabular}

Table 4 showed some data, i.e. the average score of the experimental class was 72.53 with the following details: a minimum score (50), a maximum score (100), a median (75), and a mode (75). The average score of the control class was 61 with details: a minimum score (44), a maximum score (81), a median (63), and a mode (63). A frequency distribution is a grouping of data into several classes. The following was the frequency histogram of the posttest score in experimental and control classes.

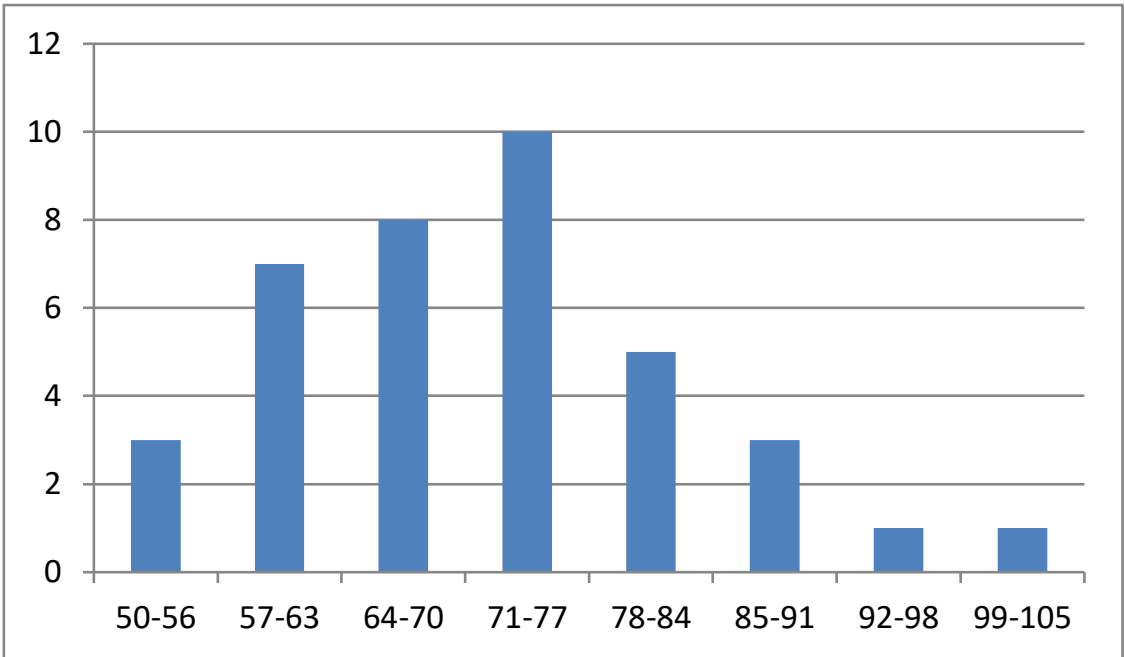

Figure 3. The histogram of the frequency distribution of experimental class posttest scores

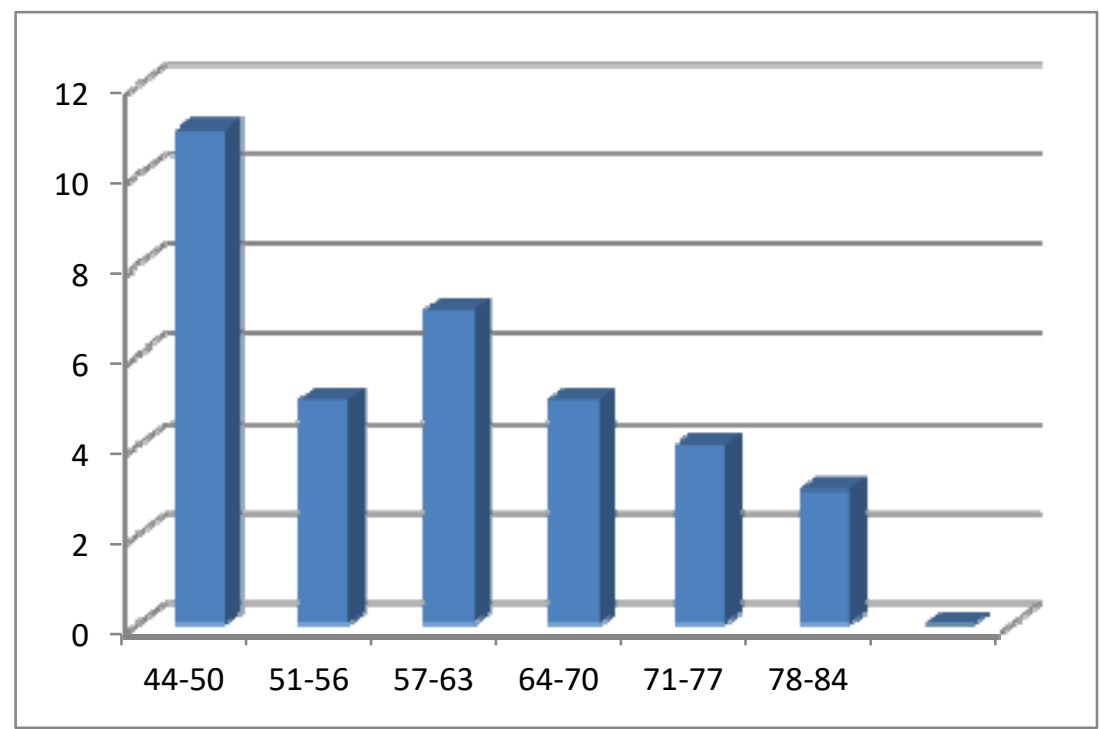

Figure 4. The histogram of the frequency distribution of control class posttest scores

\section{Discussion}

5.1 Prerequisite Analysis Test

The prerequisite analysis test in this study was the normality and homogeneity tests. The prerequisite analysis test was conducted to determine whether the research data could be used or not. 


\subsubsection{Normality Test}

Based on the research results and the obtained pretest-posttest results of the experimental and the control classes, the normality test was carried out using the Liliefors method in SPSS version 23. If the significance value is $>$ 0.05 , the data is normally distributed, and if the significance value is $<0.05$, the data is not normally distributed. The normality test result can be seen in the following SPSS output.

Table 5. SPSS Normality Test Output

\begin{tabular}{|l|l|c|c|c|}
\hline \multirow{2}{*}{} & Class & \multicolumn{3}{|c|}{ Shapiro-Wilk } \\
\cline { 2 - 5 } & & Statistics & df & \multicolumn{1}{c|}{ Sig. } \\
\hline $\begin{array}{l}\text { Students' Ability to } \\
\text { Determine }\end{array}$ & Pretest Ex & .954 & 38 & .116 \\
\cline { 2 - 5 } Character Values & Posttest Ex & .954 & 38 & .121 \\
\cline { 2 - 5 } & Pretest Control & .966 & 35 & .333 \\
\cline { 2 - 5 } & Posttest Control & .946 & 35 & .107 \\
\hline
\end{tabular}

Table 5 showed the pretest-posttest scores of the experimental and control classes in a normal distribution because the data showed a significance score of more than 0.05 . The experimental class pretest score $(0.116>$ $0.05)$, the experimental class posttest score $(0.121>0.05)$, the control class pretest score $(0.333>0.05)$ and the control class posttest score $(0.107>0.05)$.

\subsubsection{Homogeneity Test}

The homogeneity test was carried out using the posttest data which are obtained from the experimental and control classes. This test used SPSS version 23. The decision making is if the significance value is $>0.05$, the variants of the data group are the same. If the significance value $<0.05$, the variance of the data groups is not the same. The homogeneity test results can be seen in the following SPSS output.

Table 6. SPSS Homogeneity Test Output

\begin{tabular}{|c|c|c|c|}
\hline \multicolumn{4}{|c|}{ Students' Ability in Determining Character Values } \\
\hline Levene Statistic & df1 & df2 & Sig. \\
\hline .585 & 1 & 71 & .447 \\
\hline
\end{tabular}

Table 6 showed a significance value of more than 0.05 . The result is $0.447>0.05$. Hypothesis testing can be done if the analysis prerequisite test consisting of normality and homogeneity tests has met these criteria. The research hypothesis was tested using independent samples t-test using SPSS version 23. The menu used was analyze $>$ compare means $>$ independent samples t-test $>$ define group $>$ continue $>$ ok .

Independent samples t-test was conducted to determine the difference between two unpaired or independent samples. The requirement for hypothesis testing is that the data must be normally distributed and homogeneous. This test used the posttest results of the experimental and control classes. The following table showed the results.

\subsection{Posttes Analysis}

Table 7. Posttest Scores of The Experimental Class

\begin{tabular}{|c|l|c|c|l|c|}
\hline No & \multicolumn{1}{|c|}{ Students' Name } & Score & No & \multicolumn{1}{c|}{ Students' Name } & Score \\
\hline 1 & Aas Satyawati & 75 & 21 & Joy Anastasya & 94 \\
\hline 2 & Abraham Y. Muskita & 63 & 22 & Juan Soriale & 63 \\
\hline 3 & Agil & 69 & 23 & Kriselin Leatemia & 75 \\
\hline 4 & Alya Nurmala Ode & 69 & 24 & Maria Tita & 88 \\
\hline 5 & Anisa Juniar Madamar & 75 & 25 & Marisa Senewe & 88 \\
\hline 6 & Ariel Malisngorar & 63 & 26 & Mewah Neflery & 69 \\
\hline 7 & Aldi Kaimudin & 69 & 27 & Moh. Bayu Rizqiawan & 63 \\
\hline 8 & Aswinda Mochtar & 81 & 28 & Muhammad Minangkabau & 69 \\
\hline 9 & Caren Th. Siwabessy & 75 & 29 & Michelle Pattirajawane & 81 \\
\hline 10 & Christofel M. Tetelepta & 69 & 30 & Michelle Helaha & 88 \\
\hline 11 & Clarissa Watloly & 81 & 31 & Nadia Maulidya & 69 \\
\hline 12 & Dihan & 81 & 32 & Nadila Anastasya & 75 \\
\hline 13 & Edgar Persulessy & 50 & 33 & Natasya Riry & 75 \\
\hline 14 & Fidel Nelson & 63 & 34 & Nirmala Madamar & 75 \\
\hline 15 & Gloria Tita & 81 & 35 & Salwa Sahitua & 63 \\
\hline 16 & Hildawati Alamin & 69 & 36 & Vinna Tentua & 63 \\
\hline 17 & Helena Ubra & 75 & 37 & Virra Latuamury & 100 \\
\hline 18 & Husen Pelu & 50 & 38 & Wiranto Rumakamar & 50 \\
\hline 19 & Jaquine da Costa & 75 & & & Average Score \\
\hline 20 & Jo Rizky Linansera & 75 & & & \\
\cline { 1 - 3 } & & & & \\
\end{tabular}


Table 8. Posttest Scores of The Control Class

\begin{tabular}{|c|c|c|c|c|c|}
\hline No & Students' Name & Score & No & Students' Name & Score \\
\hline 1 & Agustianto & 56 & 19 & Maryam Sangaji & 63 \\
\hline 2 & Alwiyanti Ibrahim & 69 & 20 & Melinda Takaria & 69 \\
\hline 3 & Abdurahman Pelu & 63 & 21 & Mosbah Ramadhan & 75 \\
\hline 4 & Anton Lena & 81 & 22 & Muh. Rian Rumakar & 44 \\
\hline 5 & Aini Husaini & 81 & 23 & Oktovianus Ulate & 44 \\
\hline 6 & Aryan Sariman & 50 & 24 & Rosalinda Kabolosi & 75 \\
\hline 7 & Firda Amiludin & 63 & 25 & Samuel Pattipelohy & 56 \\
\hline 8 & Fahmi Arifin & 50 & 26 & Siti Pelu & 63 \\
\hline 9 & Febri Lorwens & 44 & 27 & Sausthio Sampalawa & 44 \\
\hline 10 & Firsya Sampulawa & 56 & 28 & Samad Saulatu & 56 \\
\hline 11 & Gladis Yaluhun & 75 & 29 & Sabila Suleman & 75 \\
\hline 12 & Iksan Bahari & 50 & 30 & Suny Kasiap & 50 \\
\hline 13 & Intan Ningsih & 69 & 31 & Sumini Nasir & 56 \\
\hline 14 & Jumana & 69 & 32 & Wa Desi & 63 \\
\hline 15 & Jurian Letwar & 63 & 33 & Widya & 69 \\
\hline 16 & La Arno & 50 & 34 & Yudha Lethulur & 50 \\
\hline 17 & Mauren Sana & 81 & 35 & Zulfa Rodja & 50 \\
\hline 18 & Melya Alkatiri & 63 & & Average Score & 61 \\
\hline
\end{tabular}
follows:

Based on those data, the statistical analysis of hypothesis testing using the independent samples t-test is as

$\mathrm{H}_{0}=$ There is no effect of the discovery learning model on the students' ability in determining the character education values in the folklore.

$\mathrm{H}_{\mathrm{a}}=$ There is an effect of the discovery learning model on the students' ability in determining the character education values in the folklore.

The decision-making criterion for the independent samples t-test is that if the significance value is $>0.05, \mathrm{H}_{0}$ is accepted and $\mathrm{H}_{\mathrm{a}}$ is rejected, and if the significance value is $<0.05, \mathrm{H}_{\mathrm{a}}$ is accepted, and $\mathrm{H}_{0}$ is rejected. If $\mathrm{t}$-count $<\mathrm{t}$-table, $\mathrm{H}_{0}$ is accepted, and if $\mathrm{t}$-count $>\mathrm{t}$-table, $\mathrm{H}_{0}$ is rejected. The result of the independent samples $\mathrm{t}$-test on the SPSS version 23 can be seen in the following table.

Table 9. Independent Samples T-Test Output

\begin{tabular}{|c|c|c|c|c|c|c|c|c|c|c|}
\hline & \multirow{3}{*}{\multicolumn{2}{|c|}{$\begin{array}{l}\text { Levene's } \\
\text { Test for } \\
\text { Equality of } \\
\text { Variances }\end{array}$}} & \multicolumn{7}{|c|}{ t-test for Equality of Means } \\
\hline & & & & \multirow[t]{2}{*}{$\mathrm{t}$} & \multirow[t]{2}{*}{ df } & \multirow[t]{2}{*}{$\begin{array}{l}\text { Sig. } \\
(2- \\
\text { tailed })\end{array}$} & \multirow[t]{2}{*}{$\begin{array}{c}\text { Mean } \\
\text { Difference }\end{array}$} & \multirow[t]{2}{*}{$\begin{array}{l}\text { Std. Error } \\
\text { Difference }\end{array}$} & \multicolumn{2}{|c|}{$\begin{array}{c}95 \% \text { Confidence } \\
\text { Interval of the } \\
\text { Difference }\end{array}$} \\
\hline & & & & & & & & & Lower & Upper \\
\hline \multirow{2}{*}{$\begin{array}{l}\text { Students' } \\
\text { ability in } \\
\text { determining } \\
\text { character } \\
\text { education } \\
\text { values }\end{array}$} & $\begin{array}{c}\text { Equal } \\
\text { variances } \\
\text { assumed }\end{array}$ & .585 & .447 & 4.353 & 71 & .000 & 11.52632 & 2.64817 & 6.24602 & 16.80661 \\
\hline & $\begin{array}{c}\text { Equal } \\
\text { variances } \\
\text { not } \\
\text { assumed }\end{array}$ & & & 4.348 & 70.167 & .000 & 11.52632 & 2.65099 & 6.23930 & 16.81333 \\
\hline
\end{tabular}

Table 9 showed a significant value in the Sig. (2-tailed) was 0.000 or the significance value was $<0.05(0.000$ $<0.05)$. The sample used in this study was 73 consisting of 38 students (the experimental class) and 35 students (the control class). The score of the degrees of freedom (df) can be calculated with the formula $n-2 . n$ is the number of samples, so $(\mathrm{df})=73-2=71$ with an error rate of $5 \%$. The t-table value for (df) is 1.994 . The results of the pretest and posttest in the two classes also have differences. The posttest mean score of the experimental class was 72.53, which was higher than the posttest mean score of the control class, which was 61 with a mean difference of 11.53. Besides, the average score of the experimental class was increase as seen from the pretest result of 61.66 and the average score of the posttest result was 72.53. The difference that can be seen was 10.87 . Therefore, it can be concluded that there is a positive effect of the discovery learning model on students' abilities in determining the character education values in folklore.

The process of implementing learning about folklore material in two different classes in class X SMA Negeri 3 Ambon. The two classes received different treatment. Class X MIPA-1 as the experimental class received folklore material with the discovery learning model, while class X IPS-3 as the control class used the conventional model. The application of different learning models is very influential during the learning process of folklore material in the two classes. 
The application of the discovery learning model makes students in the experimental class very enthusiastic in the learning process. Students become active, have the courage to ask questions, answer every question given, are courageous and able to convey their opinions and build good communication between peers in the group. Discovery Learning learning model makes students find their own information about the problem they want to look for based on their abilities.

The learning process carried out in the control class was very clear that students seemed passive in accepting folklore material. Only two people seem to be active in the learning process. Meanwhile, the other students only chose to remain silent and wrote down the learning material provided.

Before students in the two classes received material about folklore, the researcher gave a pretest to find out their initial abilities. The two classes were given the same material and questions. After the pretest was carried out, the researcher then delivered the folklore material to the two classes with different learning models. After the learning process was carried out, the researcher gave the two classes a posttest. The posttest is given with the aim of knowing the students' final ability after the learning process.

The pretest and posttest results in the two classes also have differences. The posttest mean score of the experimental class was 72.53 higher than the posttest average score in the control class, which was 61 with a difference of 11.53. In addition, there is an increase in the average value in the experimental class as seen from the pretest results of 61.66 and the average value of the posttest results of 72.53 with a difference of 10.87 . So, it can be concluded that the learning process using the discovery learning model has a positive influence on students' ability to determine the values of character education in folklore.

The results of the independent samples $t$ test showed that the value of $t$ count $>t$ table was $4.353>1.994$ and a significance value of $<0.05(0.000<0.05)$. Based on this calculation, it is proven that $\mathrm{H}_{0}$ was rejected and $\mathrm{H}_{\mathrm{a}}$ was accepted. So there is an effect of the Discovery Learning Model on students' abilities.

\section{Conclusion}

Based on the research results, the researchers conclude:

1. The results of the posttest in the experimental and the control classes showed a difference, namely 72.53 (experimental class) and 61 (control class). Thus, the two classes had a difference in the average posttest score of 11.53. Besides, the average score of the pretest and posttest results in the experimental class was increase, i.e. 10.87 .

2. The results of the normality and the homogeneity tests showed that the data were normally distributed and also homogeneous. Data that were normally distributed showed a significance value $>0.05$. The pretest significance value of the experimental class was $0.116(>0.05)$, the posttest significance value of the experimental class was $0.121(>0.05)$, the control class pretest significance value was $0.333 \quad(>0.05)$, and the control class posttest was $0.107(>0.05)$. While homogeneous data is evidenced by a significance value of $0.447>0.05$.

3. The results of the independent samples t-test showed that the significance value was $<0.05(0.000<0.05)$, while the value of $t$-count $>$ t-table, i.e. $4.353>1.994$

4. The results of the independent samples t-test indicated that the research hypothesis $\mathrm{H}_{0}$ was rejected and $\mathrm{H}_{\mathrm{a}}$ was accepted. So, there is an effect of the Discovery Learning Model on students' ability in determining the character education values in folklore.

\section{Acknowledgement}

Finally, we would like to thank (1) Dean of the Faculty of Teacher Training and Education at the Pattimura University Ambon who provided research grants so that this research can be carried out, (2) the head of SMA Negeri 3 Ambon and the teachers who given us the opportunity to do this research (3) students at class X of SMA Negeri 3 Ambon who participated and supported this research.

\section{References}

Alma, Buchari, et al. (2010). Guru Profesional Menguasasi Metode dan Terampil Mengajar. Bandung: Alfabeta. Atikah, Y. (2017). Pengaruh Penerapan Model Pembelajaran Discovery Learning Terhadap Hasil Belajar Tematik Terpadu pada Peserta Didik Kelas V SD Negeri 5 Metro Pusat. Faculty of Teacher Training and Education, Lampung University. Unpublished Undergraduate Thesis.

Atmazaki. (2007). Ilmu Sastra: Teori dan Terapan. Padang: UNP Press.

Budiningsih, A. (2005). Belajar dan Pembelajaran. Jakarta: Rineka Cipta.

Danandjaja, J. (1997). Folklor Indonesia: Ilmu Gosip, Dongeng, dan Lain-lain. Jakarta: Grafiti.

Hamidy. (2003). Bahasa Melayu dan Kreatifitas Sastra di Daerah Riau. Pekanbaru: Unri Press.

Hutomo, S. S. (1991). Mutiara Yang Terlupakan: Pengantar Studi Sastra Lisan. Surabaya: HISKI Jawa Timur. Kristin, F., \& Rahayu, D. (2016). Pengaruh Penerapan Model Pembelajaran Discovery Learning Terhadap Hasil Belajar IPS pada Siswa Kelas IV SD Negeri Koripan. Scolaria Jurnal Pendidikan dan Kebudayaan, 6(1), 8492. 
Kuncoro, T. D. (2018). Penerapan Model Pembelajaran Discovery Learning Untuk Meningkatkan Berpikir Kreatif dan Hasil Belajar Siswa pada Subtema Manusia dan Benda di Lingkungannya (Penelitian Tindakan Kelas pada Siswa Kelas V SD Negeri 184 Buahbatu, Kota Bandung). Pasundan University. Unpublished Undergraduate Thesis.

Kurniasih, I., \& Sani, B. (2017). Pendidikan Karakter: Internalisasi dan Metode Pembelajaran di Sekolah. Bandung: Kata Pena.

Martono, Nanang. 2010. Metode Penelitian Kuantitatif: Analisis Isi Dan Analisis Data Sekunder. Jakarta: Raja Grafindo Persada.

Priyatno, Dwi. 2017. Panduan Praktis Olah Data Menggunakan SPSS. Yogyakarta: Andi.

Reinita. (2019). Pengaruh Penerapa Model Discovery Learning Terhadap Hasil Belajar Siswa pada Pembelajaran PKn di Kelas V SD Negeri 02 Aur Kuning Bukittinggi. Jurnal Inovasi Pendidikan dan Pembelajaran Sekolah Dasar, 3(2), 13-24.

Septiani, R. (2018). Penerapan Model Discovery Learning untuk Meningkatkan Rasa Percaya Diri dan Hasil Belajar Subtema Keragaman Budaya Bangsaku. Pasundan University. Unpublished Undergraduate Thesis.

Solissa, E. M. (2019). Representasi Lokalitas dalam Nyanyian Rakyat Buru Provinsi Maluku: Kajian Etnopragmastilistika. Post Graduate Program. Surabaya State University. Unpublished Dissertation.

Sugiyono. (2017). Metode Penelitian Kuantitatif Kualitatif dan R \& D. Bandung: Elfabeta.

Supratno, H. (2010). Aktualisasi Nilai-Nilai Tradisi Lisan Berwawasan Kepulauan Sebagai Model Pendidikan Karakter Bangsa. Presented Paper in Nasional Seminar at Pattimura University Ambon on November 25, 2010.

Supratno, H., \& Darni. (2015). Folkor Lisan Sebagai Media Pendidikan Karakter Mahasiswa. Surabaya: Unesa University Press.

Syah, M. (2004). Psikologi Pendidikan dengan Pendekatan Baru. Bandung: Remaja Rosdakarya.

Wibowo, A. (2013). Pendidikan Karakter Berbasis Sastra. Yogyakarta: Pustaka Pelajar.

Zulastri. (2017). Pengaruh Penggunaan Model Pembelajaran Discovery Learning Terhadap Hasil Belajar pada Mata Pelajaran Matematika Materi Sifat Bangun Datar Siswa Kelas III MI Nurul Islam Semarang Tahun Ajaran 2016/2017. Faculty of Teacher Training and Education, Walisongo State University. Unpublished Undergraduate Thesis. 